\title{
On the proceeding of a saturation front under ponded conditions
}

\author{
Sobre el avance de un frente de saturación bajo condiciones de apozamiento
}

Fecha de entrega: 29 de junio 2012

Fecha de aceptación: 29 de enero 2013

\section{Benjamin Sinaba ${ }^{1}$, Bernhard Becker ${ }^{2}$, Wiebke Klauder ${ }^{3}$, Iván Salazar ${ }^{4}$ and Holger Schüttrumpf ${ }^{1}$}

\footnotetext{
${ }^{1}$ Lehrstuhl und Institut für Wasserbau und Wasserwirtschaft, RWTH Aachen University, Mies-van-der-Rohe-Strasse 152056 Aachen, Germany, sinaba@iww.rwth-aachen.de, schuettrumpf@iww.rwth-aachen.de

${ }^{2}$ Deltares, Rotterdamseweg 1852629 HD Delft, P.O. Box 177, 2600 MH Delft, The Netherlands, bernhard.becker@deltares.nl

${ }^{3}$ RWE Power AG, Zum Gut Bohlendorf, 50935 Bergheim, Germany, wiebke.klauder@rwe.com

${ }^{4}$ Departamento de Ingeniería Civil, Universidad Católica del Norte, Avda. Angamos 0610, Antofagasta, Chile, isalazar@ucn.cl
}

The vertical infiltration of water is a variable saturated flow process until the soil under an inundated area is completely saturated. However, in several modelling studies that regard the river-aquifer interactions, the vertical infiltration under ponded conditions is modelled as a saturated soil flow process. In order to find out whether the assumption of saturated conditions under an inundation area is suitable or not, the saturated time of the soil below an inundated area is determined. This is realised by evaluating an analytical infiltration model with two example soils under different initial conditions and for different ponding depths. The model results show, that saturation of several meters of sandy soil under ponded conditions takes place within a period of hours. For the clay example, the saturation process happens within the order of days, and if the clay is initially dry, it can take even weeks. This leads to the conclusion that saturated model approaches are suitable for sand and gravel aquifers if they are not covered with a clay layer. While the ponding depth influences the infiltration rate and the progression of the saturation front in the sandy soil, for initially wet clay the infiltration rates were found to change only marginally with the ponding depth.

Keywords: infiltration, ponded conditions, inundation, vadose zone, Richards's equation, Haverkamp infiltration model
La infiltración vertical de agua es un proceso de flujo parcialmente saturado hasta que el suelo ubicado bajo un área inundada esté completamente saturado. Sin embargo, en muchos estudios de modelación sobre interacción de agua superficial-subterránea, el proceso de infiltración vertical bajo condiciones de apozamiento es modelado como un proceso de flujo en suelo saturado. Con la finalidad de estudiar si esta simplificación es adecuada, se determina el tiempo de saturación de un suelo ubicado bajo un área inundada. Esto es realizado mediante la evaluación de un modelo de análisis de infiltración a través de dos ejemplos de suelo bajo diferentes condiciones iniciales y para diferentes profundidades de apozamiento. Los resultados del modelo indican que para un suelo arenoso bajo condiciones de apozamiento, la saturación de varios metros se lleva a cabo en horas. Para el caso de suelo arcilloso el proceso de saturación ocurre en dias, y si la arcilla se encuentra inicialmente seca puede durar incluso semanas. Esto lleva a concluir que la simplificación de un modelo saturado es adecuado para suelos arenosos y gravosos, siempre y cuando no sean subyacentes a un estrato de arcilla. En suelos arenosos la profundidad de apozamiento influye en la velocidad de infiltración y en el avance del frente de saturación, mientras que en suelos arcillosos inicialmente húmedos la profundidad de apozamiento influye marginalmente en la velocidad de infiltración.

Palabras clave: infiltración, condiciones de apozamiento, inundación, zona vadosa, ecuación de Richards, modelo de infiltración de Haverkamp 


\section{Introduction}

In recent years, floods have been causing significant damages in urban areas of Germany. One of the most disastrous flood events occurred in August 2002 in the Elbe river catchment. Rising groundwater due to high water levels of neighbouring rivers (subsurface flood) became a significant problem for the City of Dresden (see SLUG, 2003; Huber et al., 2003; Sommer and Ullrich, 2004; Kreibich and Thieken, 2008). In this case, not only bank storage effects (Freeze, 1972) were responsible for water inflow from the river into the adjacent aquifers, but also vertical infiltrations from inundated areas contributed considerably to the groundwater head rise (SLUG, 2003).

Predictive numerical simulations are an appropriate way to support regional planning or risk assessment with respect to groundwater head rising in alluvial aquifers due to high water in neighbouring rivers (Becker, 2010; Becker et al., 2012). Until the complete saturation of the soil below the inundated area the vertical infiltration under ponded conditions is a variable saturated flow process that can be represented by the Richards' equation (see Freeze and Cherry, 1979). However, in several studies the infiltration from an inundated area into the aquifer is assumed to be saturated by modelling the infiltration with a first order head boundary condition or third order leakage boundary condition in a saturated groundwater flow model (e.g. Homann, 2006; Monninkhoff and Kernbach, 2006; van Linn, 2006; Bauer et al., 2006; Koch et al., 2007; Peetz and Steckel, 2007; Sommer and Eulitz, 2007). For practical applications such a saturated approach is often chosen for the following reasons: it is computationally less expensive to assume saturated flow only, there is a lack of program features to handle infiltration processes in the used groundwater flow simulation program and in practice the additional parameters necessary for variable saturated flow are often not available for the modelling area.

This article addresses the question of how fast the saturation front under an inundated area proceeds and how long it takes until the soil below is completely saturated. A one-dimensional analytical infiltration model is evaluated for two soil examples under different initial conditions and different values of ponding depth. For hydrological studies and studies within the context of irrigation usually the infiltration rate and the cumulative infiltration are the parameters of major interest. We present diagrams with the progression of the saturation front. Within the frame of modelling subsurface floods these diagrams help to decide whether the simplification of the process of infiltration under ponded condition as saturated flow is feasible or a more advanced approach like the Richards model is necessary.

Initially, the mathematical background of the infiltration model used is introduced. Afterwards, the parameters of the example soil for which the model is evaluated are given. Subsequently, the model results are discussed. The article closes with a summary and conclusions.

\section{Mathematical infiltration model}

Haverkamp et al. (1990) present a mathematical infiltration model for infiltration under ponded conditions. The fact that it is based on physical soil parameters makes this model appropriate for this study, because parameters of example soils from the literature can be applied. Haverkamp et al. (1990) derive the cumulative infiltration I as a function of time t based on the one-dimensional Richards' equation:

$I(t)=K_{i} t+\left(h-\psi_{a}\right)\left(\theta_{s}-\theta_{i}\right) \frac{K_{s}}{q-K_{s}}+\frac{S^{2}+2 \psi_{a} K_{s}\left(\theta_{s}-\theta_{i}\right)}{2\left(K_{s}-K_{i}\right)} \ln \left[1+\frac{K_{s}-K_{i}}{q-K_{i}}\right]$

where $\mathrm{h}$ is the ponding depth, i.e. the water level above the top ground surface, being assumed as constant over time. $\theta_{\mathrm{i}}$ is the initial moisture content and $\theta_{\mathrm{s}}$ denotes the soil water content at saturation. The symbol $\mathrm{K}_{\mathrm{i}}$ stands for the initial hydraulic conductivity under unsaturated conditions and $\mathrm{K}_{\mathrm{s}}$ is the hydraulic conductivity at saturation. The sorptivity $\mathrm{S}$ describes the impact of the matrix potential $\psi$ on the infiltration of water into the soil. It embodies the influence of the capillarity capacity of dry soil in one single parameter, whereby S takes the SI-unit $\mathrm{ms}^{-0.5}$ (see Philip, 1957). Strictly, the sorptivity has meaning only in relation to an initial state of the porous medium and an imposed boundary condition (Philip, 1969). According to Freeze and Cherry (1979), $\psi_{\mathrm{a}}$ is denoted as the air entry pressure head, which is a constant soil parameter. For fine grained soils, the relationship between saturated moisture content and negative pressure head holds over a slight range $\psi>\psi_{\mathrm{a}}$ where the soil is practically saturated, but the pressure head is still negative. 
Inserting the formulation of the time dependent infiltration rate $\mathrm{q}(\mathrm{t})$

$$
q(t)=\frac{\partial I}{\partial t}
$$

into equation (1) leads to (Barry et al., 1995):

$$
\begin{aligned}
& \mathrm{t}=\mathrm{K}_{\mathrm{s}} \frac{\left(\mathrm{h}+\psi_{\mathrm{a}}\right)\left(\theta_{\mathrm{s}}-\theta_{\mathrm{i}}\right)}{\left(\mathrm{q}-\mathrm{K}_{\mathrm{s}}\right)\left(\mathrm{K}_{\mathrm{s}}-\mathrm{K}_{\mathrm{i}}\right)}-\frac{\mathrm{S}^{2}-2 \psi_{\mathrm{a}} \mathrm{K}_{\mathrm{s}}\left(\theta_{\mathrm{s}}-\theta_{\mathrm{i}}\right)}{2\left(\mathrm{q}-\mathrm{K}_{\mathrm{i}}\right)\left(\mathrm{K}_{\mathrm{s}}-\mathrm{K}_{\mathrm{i}}\right)}+ \\
& \frac{\mathrm{S}^{2}-2 \mathrm{~K}_{\mathrm{s}}\left(\theta_{\mathrm{s}}-\theta_{\mathrm{i}}\right)\left(\mathrm{h}+2 \psi_{\mathrm{a}}\right)}{2\left(\mathrm{~K}_{\mathrm{s}}-\mathrm{K}_{\mathrm{i}}\right)^{2}} \ln \left[1+\frac{\mathrm{K}_{\mathrm{s}}-\mathrm{K}_{\mathrm{i}}}{\mathrm{q}-\mathrm{K}_{\mathrm{i}}}\right]
\end{aligned}
$$

For this formulation, limits of application are given by the assumption of homogeneous isotropic soil. So layered aquifers can not be modeled and the model infiltration formula does not take into account macropore flow (see Beven and Germann, 1982). Furthermore, the horizontal movement of the soil water is not considered due to the one-dimensional approach. Finally, the model does not allow the groundwater table capillary fringe at the lower end of the model soil column as it assumes homogeneous initial conditions $\theta_{\mathrm{i}}$ (Gillham, 1984).

A formula for the position of a saturated front $z(t)$ is derived from the Laplace differential equation by Schmitz et al. (1989):

$$
z(t)=K_{s} \frac{h-\psi_{a}}{q(t)-K_{s}}
$$

The saturation front is preceded by a partly saturated transition zone (Haverkamp et al., 1990; Schmitz et al., 1989). So the position of the saturation front is defined as the intersection between the nearly saturated zone and the partially saturated zone (Schmitz et al., 1989). The space coordinate $\mathrm{z}$ is oriented in vertical direction of infiltration.

\section{Soil parameters of the model}

Chong and Green (1983) introduce an equation for sorptivity $\mathrm{S}(\theta)$ based on a combination of the Philip's equation (Philip, 1957) and the Green-Ampt's equation (Green and Ampt, 1911).

$$
\mathrm{S}(\theta)=\sqrt{2\left(\theta_{\mathrm{S}}-\theta_{\mathrm{i}}\right) \mathrm{K}_{\mathrm{S}}^{*}|\psi|}
$$

For its estimation the saturated hydraulic conductivity $\mathrm{K}_{\mathrm{s}}$, the moisture content at saturation $\theta_{\mathrm{s}}$, the initial water content $\theta_{\mathrm{i}}$ and the corresponding suction head $\psi\left(\theta_{\mathrm{i}}\right)$ have to be known. For $\mathrm{K}_{\mathrm{s}}^{*}$ in equation (5) Chong and Green (1983) use the Green-Ampt-infiltration model parameter $\mathrm{K}_{\mathrm{s}}$. But the Green-Ampt-model assumes a piston shaped proceeding of the infiltration water, so the parameter does not account for a transition zone. Therefore, Rawls and Brakensiek (1983) suggest to use

$\mathrm{K}_{\mathrm{S}}^{*}=\frac{\mathrm{K}_{\mathrm{s}}}{2}$

to account for the conductivity conditions in the partly saturated transition zone.

The relation between water content $\theta$ and the suction head $\psi$ is given by the van Genuchten approach (van Genuchten, 1978),

$$
\theta(\psi)=\theta_{\mathrm{r}}+\frac{\theta_{\mathrm{s}}-\theta_{\mathrm{r}}}{\left[1+(\alpha|\psi|)^{\mathrm{n}}\right]^{\frac{1}{\mathrm{n}-1}}}
$$

where $\theta_{\mathrm{r}}$ is the residual water content, $\alpha$ and $\mathrm{n}$ are fitting parameters. The relation between unsaturated hydraulic conductivity $\mathrm{K}$ to the corresponding water content $\theta$ is given by Schaap and van Genuchten (2006):

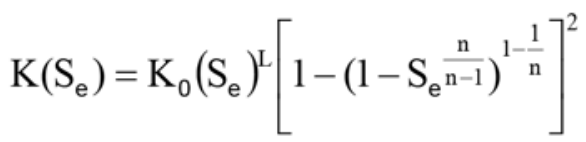

The empirical parameter $\mathrm{L}$ regards the tortuosity of the soil. $\mathrm{S}_{\mathrm{e}}$ is the relative saturation to a corresponding water content $\theta(\psi)$. In van Genuchten (1978), the relative saturation $\mathrm{S}_{\mathrm{e}}$ is noted as:

$$
\mathrm{S}_{\mathrm{e}}=\frac{\theta(\psi)-\theta_{\mathrm{r}}}{\theta_{\mathrm{S}}-\theta_{\mathrm{r}}}=\left[1+(\alpha|\psi|)^{\mathrm{n}}\right] \frac{1}{\mathrm{n}-1}
$$

To identify the air entry pressure $\psi_{\mathrm{a}}$, a water content has to be selected, whose value is near the water content $\theta_{\mathrm{s}}$ at saturation. This is necessary, because the van Genuchten model disregards a negative pressure head at complete saturation. According to the van Genuchten model the total soil saturation matches to zero suction head. 
With the equations (4) to (7), the evaluation of the infiltration model with different initial soil moisture content $\theta_{\mathrm{i}}$ is possible. The implementation of the model into a computer code is facilitated by the dimensionless representation of the model as a function of the infiltration parameter $\gamma$ (Haverkamp et al., 1990):

$$
\gamma=\frac{2 \mathrm{~K}_{\mathrm{S}}\left(\mathrm{h}-\psi_{\mathrm{a}}\right)\left(\theta_{\mathrm{S}}-\theta_{\mathrm{i}}\right)}{\mathrm{S}^{2}+2 \mathrm{~K}_{\mathrm{S}} \mathrm{h}\left(\theta_{\mathrm{s}}-\theta_{\mathrm{i}}\right)}
$$

The relationship between infiltration time and dimensionless infiltration time is given by

$$
\mathrm{t}^{*}=\mathrm{t} \frac{2\left(\mathrm{~K}_{\mathrm{s}}-\mathrm{K}_{\mathrm{i}}\right)^{2}}{\mathrm{~S}^{2}+2 \mathrm{~K}_{\mathrm{s}} \mathrm{h}\left(\theta_{\mathrm{s}}-\theta_{\mathrm{i}}\right)}
$$

Solving equation (11) allows the computation of the dimensionless cumulative infiltration I* by

$$
I^{*}=\frac{\gamma}{\mathrm{q}_{\mathrm{s}}^{*}-1}+(1-\gamma) \ln \left[1+\frac{1}{\mathrm{q}_{\mathrm{s}}^{*}-1}\right]
$$

where $\mathrm{q}_{\mathrm{s}}^{*}$ is the dimensionless infiltration rate. The dimensionless cumulative infiltration and the cumulative infiltration are related with

$$
I^{*}=\left[I-K_{i} t\right] \frac{2\left[K_{s}-K_{i}\right]}{S^{2}+2 K_{s} h\left[\theta_{s}-\theta_{i}\right]}
$$

and the implicit non-dimensional formulation of the infiltration rate is

$$
\mathrm{t}^{*}=(1-2 \gamma) \ln \left[1+\frac{1}{\mathrm{q}_{\mathrm{s}}^{*}-1}\right]+\frac{\gamma}{\mathrm{q}_{\mathrm{s}}^{*}-1}-\frac{1-\gamma}{\mathrm{q}_{\mathrm{s}}^{*}}
$$

Finally, the infiltration rate can be obtained from the dimensionless infiltration rate $\mathrm{q}_{\mathrm{s}}{ }^{*}$ with

$$
\mathrm{q}_{\mathrm{s}}^{*}=\frac{\mathrm{q}_{\mathrm{s}}-\mathrm{K}_{\mathrm{i}}}{\theta_{\mathrm{s}}-\theta_{\mathrm{i}}}
$$

To model the infiltration process, the main working step is the solution of equation (11) in order to obtain the infiltration rate for given discrete time steps. Equation (11) is a combination of fractured rational functions and an elementary transcendental function and mathematically defined in a domain of

$$
\mathrm{D}=\left\{\mathrm{q}_{\mathrm{s}}^{*} \in \mathrm{R} \mid \mathrm{q}_{\mathrm{s}}^{*}<0 \wedge \mathrm{q}_{\mathrm{s}}^{*}>1\right\}
$$

However, an unambiguous and physically feasible solution is given by $\mathrm{q}_{\mathrm{s}}{ }^{*}>1$. The bisection method has been chosen to solve these equations, because a solution interval can easily be set (see Sinaba, 2007).

The implementation of the equations into a computer code written in Matlab is called Haverkamp-infiltration-model in this paper. Input values are soil properties, points in time, and initial conditions. Model results are infiltration rate, cumulative infiltration, and the progression of the saturation front.

\section{Example soils}

The two example soils for this study correspond to the textural classes of the USDA (2009). A sand example soil is given with a composition of $95 \%$ sand, $2 \%$ silt, and 3 $\%$ clay. The second example is a clay soil, which consists of $53.2 \%$ clay, $31.7 \%$ silt, and $15.1 \%$ sand. Table 1 summarizes the soil properties and initial conditions for the example soils. Values for the parameters $\theta_{\mathrm{i}}, \theta_{\mathrm{s}}, \alpha, \mathrm{n}$, $\mathrm{K}_{\mathrm{s}}$ and L were obtained from Schaap (2009). All other parameters were obtained from the equations listed above. Initial moisture contents were chosen out of the range of field moisture contents given by Kolymbas (1998), $0.05<$ $\theta<0.1$ for sand and $0.2<\theta<0.3$ for clay.

\section{Results}

\section{Infiltration rates}

Figure 1 shows infiltration rates over time, which have been computed with the Haverkamp infiltration model for the sand example. Curves for wet and dry initial moisture contents are given for ponding depths between 0 and $2 \mathrm{~m}$. As expected, infiltration rates for initially dry sand are generally higher than for wet sand, because in the beginning of the infiltration process wet sands have a lower soil pressure head $\psi$. This leads to smaller sorptivity values which reduces the infiltration rate.

Increasing the ponding depth increases the infiltration rates, because high ponding depths cause high pressure gradients at the soil surface, although the infiltrated water 
Table1: Soil parameters of the example sand and clay for initially dry and wet conditions, respectively (Sinaba, 2007)

\begin{tabular}{|c|c|c|c|c|c|c|}
\hline \multirow{2}{*}{ Parameter } & \multirow{2}{*}{ Symbol } & \multirow{2}{*}{ Unit } & \multicolumn{2}{|c|}{ sand example } & \multicolumn{2}{|c|}{ clay example } \\
\hline & & & dry & wet & dry & wet \\
\hline Saturated moisture content & $\theta_{\mathrm{s}}$ & - & \multicolumn{2}{|c|}{0.375} & \multicolumn{2}{|c|}{0.459} \\
\hline Initial moisture content & $\theta_{\mathrm{i}}$ & - & 0.059 & 0.085 & 0.2 & 0.3 \\
\hline Residual water content & $\theta_{\mathrm{r}}$ & - & \multicolumn{2}{|c|}{0.053} & \multicolumn{2}{|c|}{0.098} \\
\hline Saturated hydraulic conductivity & $\mathrm{K}_{\mathrm{s}}$ & $\mathrm{m} / \mathrm{s}$ & \multicolumn{2}{|c|}{$7.439 \cdot 10^{-5}$} & \multicolumn{2}{|c|}{$1.708 \cdot 10^{-6}$} \\
\hline $\begin{array}{l}\text { Hydraulic conductivity at the initial } \\
\text { moisture content }\end{array}$ & $\mathrm{K}_{\mathrm{i}}$ & $\mathrm{m} / \mathrm{s}$ & $1.163 \cdot 10^{-8}$ & $1.364 \cdot 10^{-10}$ & $3.684 \cdot 10^{-13}$ & $1.1529 \cdot 10^{-13}$ \\
\hline Hydraulic conductivity near saturation & $\mathrm{K}_{0}$ & $\mathrm{~m} / \mathrm{s}$ & \multicolumn{2}{|c|}{$2.836 \cdot 10^{-6}$} & \multicolumn{2}{|c|}{$3.432 \cdot 10^{-7}$} \\
\hline Suction head & $\Psi$ & $\mathrm{m}$ & 1.7772 & 0.8115 & 98.3645 & 6.3162 \\
\hline Air entry pressure head & $\Psi_{\mathrm{a}}$ & $\mathrm{m}$ & \multicolumn{2}{|c|}{0.0514} & \multicolumn{2}{|c|}{0.0219} \\
\hline Sorptivity & $\mathrm{S}$ & $\mathrm{m} / \mathrm{s}^{0,5}$ & $6.4640 \cdot 10^{-3}$ & $4.1840 \cdot 10^{-3}$ & $6.5965 \cdot 10^{-3}$ & $1.3097 \cdot 10^{-3}$ \\
\hline van Genuchten fitting parameter & $\alpha$ & $1 / \mathrm{cm}$ & \multicolumn{2}{|c|}{0.0352} & \multicolumn{2}{|c|}{0.0150} \\
\hline van Genuchten fitting parameter & $\mathrm{n}$ & - & \multicolumn{2}{|c|}{3.1767} & \multicolumn{2}{|c|}{1.2530} \\
\hline Tortuosity factor & $\mathrm{L}$ & - & \multicolumn{2}{|c|}{-0.930} & \multicolumn{2}{|c|}{-1.561} \\
\hline
\end{tabular}

reduces the matrix potential. However, the higher the ponding depth, the lower is the influence of increasing the ponding depths on the infiltration rate for both wet and dry sand.

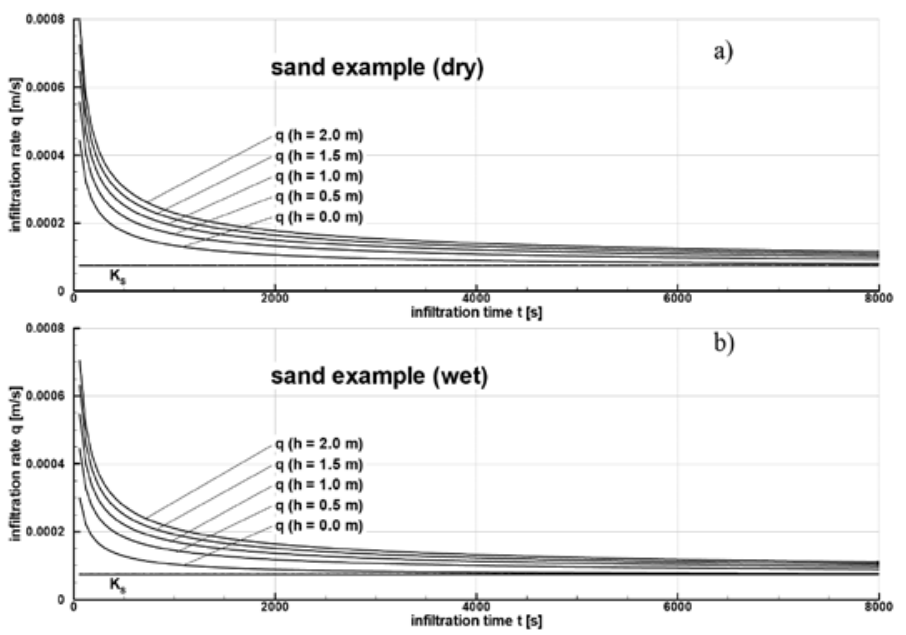

Figure 1: Infiltration rates q with ponding depths of $h=0.0,0.5$, $1.0,1.5$, and $2.0 \mathrm{~m}$ and saturated hydraulic conductivity $\mathrm{K}_{\mathrm{s}}$ for the example sand initially a) dry and b) wet

The infiltration rate with a ponding depth of $0.0 \mathrm{~m}$ represents the case of a precipitation event where the precipitation intensity is equal to the infiltration capacity q. In this case, the infiltration rate converges to a value which is equal to the saturated conductivity $\mathrm{K}_{\mathrm{s}}$.

Different to sand, the infiltration rates for initially wet example clay only change marginally with varying ponding depths and hense they can barely be distinguished (Sinaba, 2007), for this reason the infiltration curves are not shown here. For this reason the suction head $\psi$ of the clay is much higher than in the sand, computed infiltration rates for the clay is lower, because a higher initial moisture content $\theta_{i}$ and a lower value of hydraulic conductivity $\mathrm{K}_{\mathrm{s}}$ compensate the suction head value, resulting in sorptivity values almost equal to the sand example. Furthermore, clay has a lower air entry pressure $\psi_{\mathrm{a}}$.

\section{Progression of the saturation front}

Figure 2 shows the progression of the saturation front for initially dry and wet sand examples under different ponding depths. The dashed line denotes a saturated depth of one meter.

Without a water layer at the soil surface, the saturation curve is nearly linear and the infiltration period to saturate one meter of the soil from above the surface, accounts about $11000 \mathrm{~s}(3 \mathrm{~h})$ if the soil is initially dry and $6000 \mathrm{~s}$ $(1.7 \mathrm{~h})$ if it is already wet. Increasing the ponding depth increases the velocity of the saturation front for both the wet and the dry sand. However, the higher the ponding depth, the lower is the impact of the initial moisture content on the progression of the saturation front. Also the impact of increasing the ponding depth on the progression of the saturation front reduces for large ponding depths. 


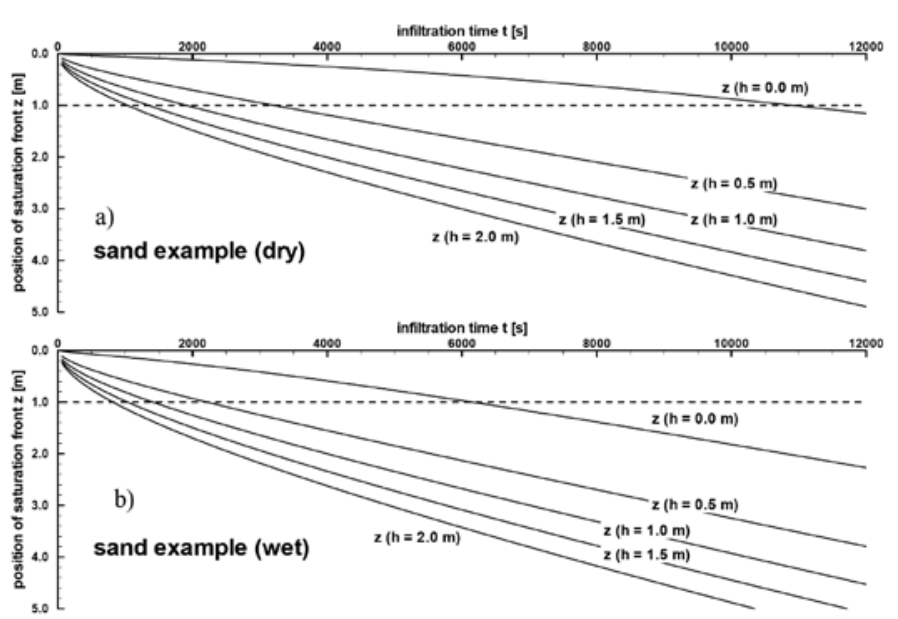

Figure 2: Position of the saturation front $\mathrm{z}$ with ponding depths of $0.0,0.5,1.0,1.5$, and $2.0 \mathrm{~m}$ for the a) dry and $\mathrm{b}$ ) wet example sand

While for the example clay the influence of varying ponding depths on the infiltration rate is only small, the ponding depth changes heavily the velocity of the saturation front progression for the wet example clay (Figure 3). Since the hydraulic conductivity depends on the moisture content of the soil, the wet clay has a higher hydraulic conductivity than the dry clay. The saturation front proceeds faster in the wet clay and the impact of the hydraulic gradient on the infiltration process and the proceeding of the saturation front is larger. With high ponding depths, saturation of an initially wet soil column of one meter takes time spans in the order of days, while the saturation of a one meter column of the initially dry example clay needs about one week.

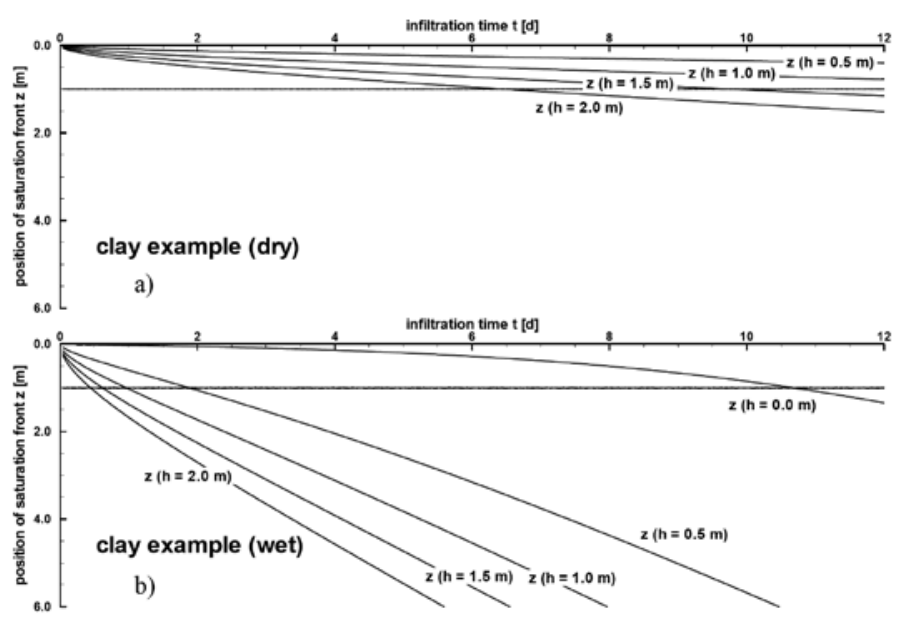

Figure 3: Position of the saturation front $\mathrm{z}$ with ponding depths of $0.0,0.5,1.0,1.5$, and $2.0 \mathrm{~m}$ for the a) dry and b) wet example clay

\section{Transition zone}

Neglecting the transition zone that precedes the saturation front, a water amount of

$$
\mathrm{I}=\left(\theta_{\mathrm{s}}-\theta_{\mathrm{i}}\right) \mathrm{z}
$$

would saturate a soil column with a length of $\mathrm{z}$. Under this assumption, the infiltrating water fills the available pore space completely with a sharp, piston-shaped wetting front like assumed in the Green-Ampt-model.

The comparison of the infiltration time after a cumulative infiltration of $I=\left(\theta_{\mathrm{s}}-\theta_{\mathrm{i}}\right) \cdot 1 \mathrm{~m}$ has been achieved with the time after the saturation front has reached a depth of one meter allows conclusions on the shape of the transition front. Table 2 shows the results of this comparison: for high ponding depths the dry and wet example sand values only differ slightly (Table 2 only shows the data for wet sand). So a nearly piston-shaped wetting front of the saturation front can be concluded for the sand soil. Because the two time values differ significantly for dry clay, a large fraction of the infiltrated water is stored in the transition front that precedes the saturation front in the clay soil. However, displaying this transition front is not possible with the used infiltration formulas, because the equations do not provide any information on the moisture distribution.

Table 2: Infiltration time $\mathrm{t}$ in seconds after the cumulative infiltration has reached the value of $I=\left(\theta_{s}-\theta_{0}\right) \cdot 1 \mathrm{~m}$ and the time after the saturation front has reached $1 \mathrm{~m}$ for two example soils

\begin{tabular}{|c|r|r|r|r|}
\hline \multirow{2}{*}{$\begin{array}{c}\text { ponding } \\
\text { depth } \mathrm{h}, \mathrm{m}\end{array}$} & \multicolumn{2}{|c|}{ wet sand } & \multicolumn{2}{c|}{ dry clay } \\
\cline { 2 - 5 } & $\mathrm{I}=0.290 \mathrm{~m}$ & $\mathrm{z}=1.0 \mathrm{~m}$ & $\mathrm{I}=0.259 \mathrm{~m}$ & $\mathrm{z}=1.0 \mathrm{~m}$ \\
\hline 0.0 & 2316 & 6150 & 1536 & 21491688 \\
\hline 0.5 & 1343 & 2213 & 1512 & 3146941 \\
\hline 1.0 & 982 & 1408 & 1500 & 1445804 \\
\hline 1.5 & 780 & 1035 & 1448 & 844110 \\
\hline 2.0 & 648 & 818 & 1470 & 557194 \\
\hline
\end{tabular}

\section{Summary and conclusions}

In several studies the infiltration of water from an inundated area into an aquifer below the inundation area is modelled by applying saturated flow boundary conditions. A prerequisite of this assumption is that the pore space under the inundated area is initially saturated or at least the saturation front under the inundation area proceeds 
fast enough to justify neglecting the variably saturated flow processes. In order to estimate how long it takes to saturate the pore space under an inundated area, an analytical infiltration model has been used for two different example soils under different initial conditions. While many infiltration-related studies address hydrological questions or irrigation problems where the infiltration rate or the cumulative infiltration is of major interest, this study presents diagrams with the position of the saturation front over time. These diagrams can help practitioners dealing with infiltration to decide whether the simplification of the process of infiltration under ponded condition as a saturated flow is feasible or a more advanced approach like the Richards's model is necessary. The motivation for this work arises from the predictive modelling of subsurface floods, but the results of this study might also be of interest for other applications where infiltrations may play a main role, for example the infiltration of contaminants from copper mining waste dumps (see e.g. Salazar, 2011).

The results show that the saturation of several meters of sandy soil below an inundation takes place within the order of hours. For many groundwater models this will cover only a few simulation time steps, so the assumption of saturation under an inundated area will apply for groundwater models of sand or gravel aquifers. The higher the ponding depth, the faster does the saturation front proceed, however, the impact of increasing the ponding depth on the progression of the saturation front reduces for large ponding depths.

For the clay soil example, orders of days were found to be the time period necessary to saturate one meter of soil. If the clay is initially dry, it takes even weeks to saturate a clay soil of one meter. Thus, the assumption of saturation below an inundated area will not be applicable for aquifers that are covered with a dry clay layer. However, if the clay layer is initially wet, the saturation front moves through a clay layer of one meter thickness comparatively fast, but it still takes several hours.

For the analyzed sand example, the ponding depth does not only influence the velocity of the progression of the saturation front, it also has a remarkable influence on the infiltration rate, while for initially wet clay, the infiltration rates were found to change only marginally with the ponding depth. The infiltration into sand occurs with a piston-shaped saturation front nearly without a transition zone. During infiltration into clay a larger fraction of the infiltrated water is distributed in the transition zone that precedes the saturation front. Thus, the arrival time of infiltrating water at a specific position, e.g. the groundwater level, can be estimated roughly by the progression of the saturation front for sandy soil. This is not possible for clay, because a distinct transition zone precedes the saturation front here.

As the assumption of saturated conditions under an inundated area does not apply in general, applicable approaches to handle the infiltration from an inundated area for groundwater models are desirable. With such modelling features the opportunities to perform predictive simulations of subsurface flood events will improve.

\section{References}

Barry, D.A., Parlange, J.Y., Haverkamp, R. and Ross, P.J. (1995). Infiltration under ponded conditions: 4. An explicit predictive infiltration formula. Soil Science 160(1): 8-7

Bauer, P., Gumbricht, T. and Kinzelbach, W. (2006). A regional coupled surface water/groundwater model of the Okavango Delta, Botswana. Water Resources Research 42, No. W04403

Becker, B.P.J. (2010). Zur gekoppelten numerischen Modellierung von unterirdischem Hochwasser. Dissertation RWTH Aachen University

Becker, B.P.J., Forberig, S., Flögel, R., Schüttrumpf, H. and Köngeter, J. (2012). On the determination of groundwater levels for hazard maps of groundwater head rise induced by high water. WasserWirtschaft 12, 10-16

Beven, K. and Germann, P. (1982). Macropore and water flow in soils. Water Resources Research 18 (5): 1311-1325

Chong, S.K. and Green, R.E. (1983). Sorptivity measurement and its application. In: Proceedings of the National Conference on Advances in Infiltration, American Society of Agricultural Engineers, 12-13 Dec. 1983, Chicago, Illinois, 82-91

Freeze, R. A. (1972). Role of Subsurface Flow in Generating Surface Runoff. 1. Base Flow Contributions to Channel Flow. Water Resources Research 8, No. 3, 609-623

Freeze, R.A. and Cherry, J.A. (1979). Groundwater. Prentice Hall, Englewood Cliffs, New Jersey

Gillham, R.W. (1984). The capillary fringe and its effect on water table response. Journal of Hydrology 67, 307-324 
Green, W.H. and Ampt, G.A. (1911). Studies on Soil Physics: 1. Flow of Air and Water through Soils. The Journal of Agricultural Science 4, 1-4.

Haverkamp, R., Parlange, J.Y., Starr, J.L., Schmitz, G. and Fuentes, C. (1990). Infiltration under ponded conditions: 3. A predictive equation based on physical parameters. Soil Science 149, No. 5, 292-300

Homann, C. (2006). Automatische Optimierung von Grundwasserhaltungen in von Hochwasser beeinflussten Aquiferen. Dissertation RWTH Aachen University.

Huber, G., Hiller, G. and Braune, A. (2003). Konzepte des Hochwasserschutzes für die Bauten des Freistaates Sachsen im Historischen Stadtkern von Dresden. In: Umweltamt Landeshauptstadt Dresden and Dresdner Grundwasserforschungszentrum e.V. (eds.), Hochwassernachsorge Grundwasser Dresden, Wissenschaftliche Tagung zum BMBF-Forschungsprojekt/8.Oktober 2003/ Dresden, Rathaus/Tagungsband. Dresden Druckerei und Verlag Christoph Hille, 57-62

Koch, A., Meon, G. and Leibundgut, C. (2007). Die gekoppelte Simulation der 2D-Oberflächenwasser- und 3D-Grundwasserströmung im Rahmen eines Expertensystems zur Modellierung der hydrodynamischen Wechselwirkungen einer Flusslandschaft. In: Meon, G., Sauter, Führböter and Wolf (eds.): Niedersächsisches Grundwasserkolloquium 21.-22. Februar 2007 in Braunschweig. Grundwasser, Hochwasser und Salzwasser/Konzepte zur Risikominimierung. Stuttgart: E. Schweizerbart'sche Verlagsbuchhandlung (Nägele u. Obermiller), Zentralblatt für Geologie und Paläontologie/Teil I Allgemeine, Angewandte, Regionale und Historische Geologie Vol. 2007, No. 1/2, 99-114.

Kolymbas, D. (1998). Geotechnik: Bodenmechanik und Grundbau. Springer, Berlin.

Kreibich, H. and Thieken, A.H. (2008). Assessment of damage caused by high groundwater inundation. Water Resources Research 44, No. 9. http://dx.doi.org/10.1029/2007WR006621.

Monninkhoff, B. and Kernbach, K. (2006). Coupled surface water - groundwater modeling for planning of flood retention in the Lower Havel area. In: Proceedings of the: International FEFLOW User Conference, September 10-15, 2006 Berlin, Germany, 115-124.

Peetz, J.-V. and Steckel, B. (2007). 3-code coupling in flood simulation. In: MpCCI 8th user forum proceedings, february 13 and 14, 2007, 108-116.

http://www.mpcci.de/fileadmin/mpcci/Userforum/MpCCI_8th_ UserForum.pdf
Philip, J.R. (1957). Theory of infiltration: 1. The infiltration equation and its solution. Soil Science 83(5), 345-358

Philip, J.R. (1969). Theory of infiltration. Advances in Hydroscience 5, Academic Press, 215-296.

Rawls, J.W. and Brakensiek, D.L. (1983). A procedure to predict Green and Ampt infiltration parameters. In: Proceedings of the National Conference on Advances in Infiltration, American Society of Agricultural Engineers: 12.-13. Dec. 1983, Chicago, Illinois, 102-112

Salazar, I. (2011). Beitrag zur Verringerung der Schadstoffkonzentration in heterogenen porösen Medien. Dissertation RWTH Aachen University.

Schaap, G. M. (2009). Rosetta: A computer program for estimating soil hydraulic parameters with hierarchical pedotransfer functions. url: http://ag.arizona.edu/research/ rosetta/download/rosetta.pdf, checked 2009-12-10.

Schaap, M.G. and van Genuchten, M.T. (2006). A modified Mualem-van Genuchten formulation for improved description of the hydraulic conductivity near saturation. Vadose Zone Journal 5, No. 1, 27-34

Schmitz, G., Haverkamp, R., Parlange, J.Y. and Liedl, R. (1989). Infiltration bei eingestauter Bodenoberflaeche. 1. Analytische Lösung der Infiltrationsgleichung und praktische Berechnung der Versickerung. Zeitschrift für Kulturtechnik und Landentwicklung 30, No. 2, 121-131

Sinaba, B. (2007). Zur Infiltration bei eingestauter Bodenoberfläche. Diplomarbeit RWTH Aachen University

SLUG Sächsisches Landesamt für Umwelt und Geologie (2003). Einfluss des August Hochwassers 2002 auf das Grundwasser. Materialien zur Wasserwirtschaft.

Sommer, T. and Ullrich, K. (2004). Das unsichtbare Hochwasser - Auswirkungen des August-Hochwassers 2002 auf das Grundwasser im Stadtgebiet von Dresden. In: 34. IWASA Internationales Wasserbau-Symposium Aachen 2004 : Hochwasserschutz - eindeichen oder ausweichen. Mitteilungen des Inst. f. Wasserbau und Wasserwirtschaft, RWTH Aachen. Aachen: Shaker, 203-224.

Sommer, T. and Eulitz, K. (2007).Auswirkungen des Hochwassers auf das Grundwasser/Phänomene und Modellansätze. In: Meon, Sauter, Führböter and Wolf (eds.): Niedersächsisches Grundwasserkolloquium 21.-22. Februar 2007 in Braunschweig: Grundwasser, Hochwasser und Salzwasser/Konzepte zur Risikominimierung. Stuttgart: E. Schweizerbart'sche Verlagsbuchhandlung (Nägele u. Obermiller), Zentralblatt für Geologie und Paläontologie/Teil I Allgemeine, Angewandte, 
Regionale und Historische Geologie Vol. 2007, No. 1/2, 7-15

USDA United States Department of Agriculture (2009). USDA Textural Classification Chart. url: http://www.gintsoftware.com/ downloads/reports/usda_textural_class.pdf, checked 2009-12-10. van Genuchten, R. (1978). Calculating the unsaturated hydraulic conductivity with a new closed-form analytical model. Water Resources Program: Department of Civil Engineering, Princeton University. van Linn, A. (2006). Automatische Optimierung zur Bewertung und Risikoanalyse einer Hochwasserschutzmaßnahme. Dissertation RWTH Aachen University. 